\title{
Intervence české vzdělávací politiky ve vztahu $k$ výzkumně doloženým poznatkům a doporučením: př́pad požadavků na kvalifikaci učitele
}

\author{
Vladimíra Spilková, Irena Reimannová
}

\begin{abstract}
Abstrakt: Cílem studie je analýza prìistupu české vzdèlávaci politiky ke kvalifikačním požadavkiim na vstup do učitelské profese $v$ souvislosti s aktuálně projednávanou novelou zákona c. 563/2004 Sb., o pedagogických pracovnicich, a zejména jejim kontroverznim $\mathbb{S}$ 9a odst. 1, který otevírá učitelskou profesi vysokoškolsky vzdèlaným odbornikuim bez pedagogické kvalifikace. Na prípadu legislativního procesu v daném tématu je dokumentován a analyzován prístup české vzdèlávaci politiky k profesi učitele v kontextu vztahü vrcholné decizni sféry k výzkumným zjiště́nim, mezinárodnim trendiom a strategiím relevantnim pro kvalitu učiteli v 21. století.

Zkoumáni uvedeného prípadu vzdělávací politiky je založeno na metodologii desk research. Kličové zdroje dat predstavuji dokumenty: legislativni (ruizné verze novely - snèmovni a senátní tisk novely, pozménovaci návrhy, stenozápisy z jednáni obou komor Parlamentu ČR), dokumenty odborné a strategické (na národní i evropské úrovni), MŠMT, stanoviska düležitých aktérù a tiskové zprávy (profesni asociace, odborníci, neziskové organizace, př́spèvky na sociálních sitich), mailová komunikace jedné $z$ autorek príspèvku s poslanci a senátory.

V diskusi výsledki jsou kriticky reflektovány obsah a zpuisob zdiovodñováni devalvace kvalifikačnich požadavkü na ucittele ze strany politiku. Je zhodnocena relevance a korektnost hlavnich di̊vodù prezentovaných predkladatelem novely - MŠMT a dalšimi klícovými aktéry legislativniho procesu. Dále mira využití relevantnich výzkumných dat a doporučeni v procesu tvorby návrhu a politického rozhodováni v otázce zákonných požadavkư na kvalifikaci učitele.
\end{abstract}

Klíčová slova: vzdělávací politika, evidence-based prístup, kvalifikační požadavky, výzkum učitelské profese, de-profesionalizace učitelstvi, de-kvalifikačni novela, de-profesionalizačni novela

\section{ÚvoD}

Kvalita ve vzdělávání patří $\mathrm{k}$ nejfrekventovanějším termínům v současném pe- dagogickém diskurzu, k prioritám výzkumu i deklarovaným prioritám vzdělávací politiky ve většině vyspělých zemí. Politická rétorika na mezinárodní i národní 
úrovni obsahuje jak obecné proklamace, tak výčty konkrétních opatření a intervencí ke zvyšování kvality.

Řada výzkumných studií doložila, že kvalitu školního vzdělávání a vzdělávací výsledky žáků zásadním způsobem ovlivňuje kvalita/profesionalita učitelů (Darling-Hammond, 2000; Hanusek, Kain \& Rivkin, 2005; Crone \& Teddlie, 1995). Některé výzkumy prokázaly, že má větší vliv na vzdělávací výsledky žáků než např. kvalita kurikula nebo materiální podmínky a vybavení škol (Hattie, 2009; Barber \& Mourshed, 2007).

Učitelé jsou považováni (s oporou o výzkumná data) za klíčový prvek zásadně ovlivňující kvalitu celé vzdělávací soustavy (např. OECD: Evaluating and Rewarding the Quality of Teachers, 2009). Všeobecně známé jsou výroky: „Kvalita vzdělávacích systémů nemůže překonat kvalitu učitelů, kteří $\mathrm{v}$ něm pracuji “ (Barber \& Mourshed, 2007) nebo slovy J. Kotáska (1991, s. 11) „s odbornou a lidskou kvalitou učitelů stojí a padá kvalita školství".

Učitelé mají zásadní vliv nejen $\mathrm{z}$ hlediska vzdělávacích výsledků žáků a etického a hodnotového působení na žáky, ovlivňují ale také úspěšnost implementace vzdělávacích politik. $\mathrm{Na}$ základě výzkumně potvrzené stěžejní role učitelů $\mathrm{v}$ uskutečňování reforem a zavádění inovací se učitelé jako klíčoví aktéŕi vzdělávací politiky od devadesátých let 20. století postupně dostávají do centra její pozornosti ve většině vyspělých zemí.

Pohled mezinárodní optikou na domácí situaci v této oblasti ukazuje pro- pastné rozdíly. Nezájem české vzdělávací politiky o klíčová témata učitelské profese byl popsán řadou autorů (napřr. Urbánek, 2005, 2013; Spilková, 2016; Hanušová et al., 2017; Vítečková, 2018). Podrobné kritické reflexi prrístupů české vzdělávací politiky $\mathrm{k}$ učitelské profesi a učitelskému vzdělávání $\mathrm{v}$ prủběhu 25 let (po roce 1989) byla věnována přehledová studie V. Spilkové (2016). Analýza dokumentů, legislativních návrhů i významných zásahů decizní sféry doložila na konkrétních př́kladech dlouhodobý nezájem, resp. převážně proklamativní pozornost české vzdělávací politiky a decizní sféry, které v kombinaci s nekoncepčními a nesystémovými intervencemi způsobily eskalaci problémů a postupně prohlubovaly krizi učitelské profese.

$\mathrm{V}$ návaznosti na tento text se nyní zaměřujeme na analýzu př́stupu české vzdělávací politiky ke kvalifikačním požadavkům na vstup do učitelské profese v souvislosti s aktuálně projednávanou novelou zákona č. 563/2004 Sb., o pedagogických pracovnících, a jejím kontroverzním $\$ 9$ a odst. 1. Studii koncipujeme jako reflexi tvorby a realizace vzdělávací politiky na prrípadu legislativního vymezení kvalifikačních požadavků na učitele v této novele a průběhu jejího projednávání. Pro poznání a hlubší porozumění danému fenoménu, který vyvolal ostré diskuse mezi odbornou i širší veřejností, považujeme za důležité jeho zasazení do širšího kontextu vývoje př́stupů vzdělávací politiky v této oblasti po roce 1989. 
1. NÁVRH DE-PROFESIONALIZAČNÍ NOVELY ZÁKONA Č. 563/2004

SB., O PEDAGOGICKÝCH PRACOVNÍCÍCH, V KONTEXTU VÝVOJE PŘíSTUPŮ VZDĚLÁVACÍ POLITIKY

KE KVALIFIKAČNÍM POŽADAVKŮM NA UČITELE

Od poloviny devadesátých let 20. století se jako evergreen ze strany české vzdělávací politiky a decizní sféry opakovaly snahy o snižování požadavků na kvalifikaci učitelů (Maňák, 1995; Spilková et al., 2004; Spilková, 2016). První návrh na snížení nároků na kvalitu a délku učitelského vzdělávání byl předložen již v roce 1995 v dokumentu MŠMT pod názvem Učitel. Pro učitele 1. stupně ZŠ bylo navrhováno bakalářské studium na neuniverzitní instituci (předmětem úvah bylo i bakalářské

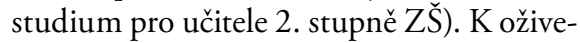
ní snah degradovat požadavky na tuto kategorii učitelů (pouze bakalářské studium) došlo také v souvislosti s tzv. Boloňskou deklarací a tlakem na strukturaci studia, a to za podpory nemalé ćásti politiků a MŠMT. V tomto smyslu má zásadní význam zákon č. 563/2004,v němž je závazně vymezeno magisterské studium jako podmínka pro uznání učitelské kvalifikace.

I po přijetí tohoto zákona v roce 2004 však pokračovalo zpochybňování kvalifikačních předpokladi̊ a snaha snižovat požadavky na vzdělanostní úroveň učitelů $\mathrm{v}$ podobě návrhů na novelizaci zákona. Některé legislativní návrhy se podařilo odvrátit (např. návrh novely zákona z roku 2007 předsedy školského výboru Poslanecké sněmovny Parlamentu ČR W. Bartoše umožňující působení středoškolsky vzdělaných učitelů na základních školách jako plně kvalifikovaných), jiné prošly (novely z roku 2006 a 2011). Zde je důležité zmínit také dokument na vládní úrovni z roku 2011 (Závěrečná zpráva NERV), v němž je opět navrhováno snížení zákonného požadavku na bakalářskou úroveň, tentokrát na kvalifikaci pro učitele 2. stupně ZŠ (požadavek magisterského studia měl být ponechán pouze pro učitele 1. stupně $Z \check{S}$ a ředitele).

Tyto novely lze považovat za projev určité rezignace vzdělávací politiky na kvalitu učitelů a na podporu zvyšování jejich profesionality. Skutečný průlom, který zesiluje tento negativní trend v české vzdělávací politice, však představuje další vládní novela zákona č. 197/2014 Sb., která umožňuje s účinností od 1. ledna 2015 vykonávat př́mou pedagogickou činnost vybraným skupinám pedagogických pracovníků bez odborné kvalifikace. Touto legislativní úpravou řeší MŠMT „časovanou bombu“ v podobě dlouhodobě neřešeného problému působení značného množství nekvalifikovaných učitelů na základních a středních školách (Spilková \& Wildová, 2014). ${ }^{1}$

\footnotetext{
1 Analytická zpráva z mimorádného šetreni o nekvalifikovaných pedagogických pracovních (únor 2014) přináší údaje o celkovém počtu 11090 učitelů bez odborné kvalifikace pro př́mou pedagogickou činnost, tj. 8,2\%. Po přepočtení na plné úvazky se jedná o 8380 učitelů, tj. 6,4\%. Největší počet nekvalifikovaných učitelů je na středních školách (téměr 5400 učitelů, po přepočtení na plné úvazky 4500 učitelů).
} 
Novela z roku 2014 dává řediteli školy pravomoc „písemně uznat předpoklad odborné kvalifikace“ u pracovníka pracujícího na základní či střední škole na částečný úvazek (max. poloviční), který je „výkonným umělcem, výtvarným umělcem, trenérem, uznávaným odborníkem v oboru“ pro výuku předmětu uměleckého nebo odborného zaměření. Výjimka z požadavku odborné kvalifikace se týká také výuky cizích jazyků a učitelů ve věku nad 55 let nebo s 20 roky prrímé pedagogické činnosti. Novela umožňuje řadu výjimek a svou vágností $\mathrm{v}$ některých aspektech připouští různorodý výklad. Zavádí novou kategorii v systému kvalifikovaných pedagogických pracovníků „uznávaný odborník“, který je předobrazem tzv. odborníka z praxe, který hraje významnou roli v zatím posledním návrhu novely z roku 2019.

Průlomové je přenesení odpovědnosti za kvalitu učitelů a jejich kvalifikovanost ze strany státu na ředitele škol. Něco podobného je nepředstavitelné u jakékoli jiné tzv. regulované profese $s$ tak vysokou společenskou závažností. Je to nemyslitelné dokonce u některých dělnických profesí, v oblasti služeb, řemesel apod.

Aktuálně projednávaná novela, jejíž pojetí a způsob projednávání je předmětem této studie, přináší prolomení další hranice a představuje již útok na samotnou podstatu učitelské profese. $\mathrm{Z}$ tohoto důvodu ji označujeme jako de-profesionalizační a de-kvalifikační. Označení de-profesionalizační vyjadřuje zpochybnění důležitosti specifických profesních znalostí a dovedností nutných pro kvalitní výkon profese, které odlišují práci profesio- nálů od poučených, byt' třeba i osobnostně disponovaných laiků a amatérů. Označení de-kvalifikační vyjadřuje radikální snížení kvalifikačních požadavků na učitele, které lze považovat za faktickou rezignaci na kvalifikaci pro vstup do učitelské profese.

\section{Cíl STUdie A MetodologickÝ PŘísTUP}

Cílem studie je analýza př́stupu české vzdělávací politiky ke kvalifikačním požadavkům na vstup do učitelské profese $\mathrm{v}$ souvislosti $s$ aktuálně projednávanou novelou zákona č. 563/2004 Sb., o pedagogických pracovnících, a jejím kontroverzním $\$ 9$ a odst. 1. Zkoumání případu legislativního vymezení požadavků na kvalifikaci učitele $\mathrm{v}$ této novele a průběhu jejího projednávání cílí na poznání a hlubší porozumění vztahu mezi politickým rozhodováním, výzkumně doloženými poznatky a způsobem jejich zprostředkování politikům.

Jako hlavní výzkumné otázky byly zvoleny: (1) Jaké důvody pro snížení kvalifikačních požadavků v de-profesionalizační novele formulovali předkladatel novely - MŠMT, poslanci a senátoři Parlamentu ČR? (2) Jaké argumenty prezentovali politici - zastánci i odpůrci novely - ve svých stanoviscích $\mathrm{v}$ průběhu legislativního procesu? (3) Jaké názory vyjadřovali v průběhu projednávání novely další aktéři z řad odborné i širší veřejnosti?

$\mathrm{Na}$ uvedené otázky vztažené k případu de-profesionalizační a de-kvalifikační novely navázaly výzkumné otázky obec- 
nějšího charakteru: (1) Jak česká vzdělávací politika přistupuje $\mathrm{k}$ učitelství jako regulované profesi spojené $s$ určitými pracovními rolemi, $\mathrm{k}$ jejichž výkonu je regulovaný a omezený př́stup? (2) Jak jsou při tvorbě české vzdělávací politiky a při rozhodovacích procesech $\mathrm{v}$ oblasti učitelské profese využívána výzkumná zjištění a výzkumně doložená doporučení na evropské i domácí úrovni?

Zkoumání uvedeného př́padu vzdělávací politiky, vymezeného výzkumnými otázkami, je založeno na metodologii desk research. ${ }^{2}$ Jde o sekundární výzkum využívající zdroje, které byly v minulosti shromážděny za jiným účelem. Jedná se o data získaná z širokého spektra zdrojů, jakými jsou úřední dokumenty (aktuální i retrospektivní), odborné publikace, výzkumné zprávy, výstupy masových médií a virtuální data (internetové stránky, obsahy internetových diskusí aj.).

Klíčovými zdroji dat našeho výzkumu byly dokumenty legislativní (různé verze novely - sněmovní a senátní tisk novely, pozměňovací návrhy, stenozápisy z jednání obou komor Parlamentu ČR), dokumenty odborné a strategické (na národní i evropské úrovni), dokumenty MŠMT, stanoviska důležitých aktérů, tiskové zprávy (profesní asociace, odborníci, neziskové organizace, př́spěvky na sociálních sítích - www. pedagogicka-komora.cz) a e-mailová komunikace jedné $\mathrm{z}$ autorek př́spěvku $s$ poslanci a senátory.
Získaná data byla analyzována $\mathrm{v}$ několika fázích, které odpovídaly časové posloupnosti procesu projednávání novely zákona. $\mathrm{V}$ první fázi jsme analyzovaly vybrané pasáže vládní novely zákona, které se dotýkaly změny kvalifikačních požadavkủ. $\mathrm{V}$ dalších fázích jsme zaznamenávaly průběh projednávání v Poslanecké sněmovně Parlamentu ČR (dále Sněmovna) a v Senátu Parlamentu ČR (dále Senát), pozměňovací návrhy a výsledky hlasování. Současně jsme analyzovaly jak prohlášení a stanoviska predkladatele novely a politiků zdůvodňující snížení kvalifikačních nároků na učitele, tak obsah a způsob argumentace kritiků návrhu legislativních úprav. Ověřovaly jsme korektnost použitých argumentů předkladatele a podporovatelů novely, které měly legitimizovat potřebu změn, $v$ mezinárodních dokumentech a relevantních odborných zdrojích.

\section{VÝZKUMNÁ ZJIŠTĚNÍ}

Prezentaci zjištění uvádíme stručným přehledem základních dat týkajících se procesu projednávání novely zákona (tento proces není zatím uzavřený). $\mathrm{V}$ chronologickém popisu identifikujeme důležité mezníky v procesu projednávání vládního návrhu novely zákona v obou komorách Parlamentu ČR. Následně se podrobněji věnujeme roli klíčových aktérů. Jsou to MŠMT a politici sněmovny a senátu, $u$ nichž se výběrově zaměřujeme pouze na př́stup

\footnotetext{
2 https://www.rupertwegerif.name/blog/how-to-write-desk-based-research-in-education https://www.userfocus.co.uk/articles/desk-research-the-what-why-and-how.html
} 
k radikálnímu snížení kvalifikačních požadavků na učitele (zejména $\$ 9 \mathrm{a}$ ve vládním návrhu). Prezentujeme také stanoviska dalších aktérů z řad odborné i širší veřejnosti.

\subsection{Přehled základních dat týka- jících se procesu projednávání novely zákona č. 563/2004 Sb., o pedagogických pracovnících ${ }^{3}$}

Vláda předložila sněmovně návrh novely zákona 7. června 2019 (sněmovní tisk 503). V průběhu prvního až třetího čtení (28. ledna 2020 až 27. ledna 2021) se ukázala široká politická shoda. Projednávání novely probíhalo vcelku bezproblémově, byt' byla formulována řada pozměňovacích návrhů (jejich přehled viz sněmovní tisky 503/2 a 503/3). Dne 27. ledna 2021 sněmovna novelu zákona schválila $s$ pozměňovacími návrhy. $\mathrm{O}$ míře politické shody svědčí hlasování - z 99 hlasujících poslanců a poslankyň bylo 94 pro, dva byli proti a tři se zdrželi hlasování.

Dne 22. února 2021 byl návrh zákona postoupen senátu (senátní tisk 53). ${ }^{4}$ 9. března 2021 doporučil garanční výbor Senátu vrátit projednávaný návrh zákona Sněmovně s pozměňovacím návrhem, který se netýkal kvalifikačních požadavků na učitele $\mathrm{v} \$ 9 \mathrm{a}$. Po projednání v plénu Senátu 21. března 2021 bylo schváleno vrácení návrhu zákona do Sněmovny $s$ pěti pozměňovacími návrhy bez vztahu ke kvalifikačním požadavkům. I v Sená- tu ukázalo hlasování velkou politickou shodu - 61 pro, nikdo nebyl proti a čtyři senátoři se zdrželi hlasování. Ve Sněmovně byl zahájeno projednávání vráceného návrhu zákona 13. dubna 2021 (sněmovní tisk 503/5) a poté bylo přerušeno.

\subsection{Role klíčových aktérů}

\section{MŠMT}

V prosinci 2018 posílá ministr školství po skončeném připomínkovém řízení návrh novely zákona $\mathrm{k}$ projednání na vládě. $\mathrm{V}$ prezentaci hlavních principů navrhované právní úpravy dominuje vysvětlení průlomové změny $\mathrm{v}$ požadavcích na odbornou kvalifikaci učitelů základních a středních škol. S odkazem na programové cíle vlády a zde formulovaný důraz na posílení postavení ředitelů škol a jejich odpovědnosti v oblasti odborné a pedagogické úrovně vzdělávání zdůvodňuje ministr legislativní zakotvení další kvalifikační cesty $\mathrm{k}$ učitelské profesi. Kromě existujících dvou standardních cest (pětileté učitelské studium nebo pětileté neučitelské studium a doplňující pedagogické studium v rozsahu minimálně 250 hodin) zavádí návrh novely třetí cestu v podobě přiznání kvalifikace na tři roky ředitelem školy - tzv. ředitelskou kvalifikaci.

Reditel školy by tak mohl uznat předpoklad odborné kvalifikace pro prímou pedagogickou činnost učitele všeobecně vzdělávacích předmětů na 2 . stupni základní školy nebo na střední škole (nejen

https://www.psp.cz/sqw/historie.sqw?o=8\&t=503

4 https://www.senat.cz/xqw/xervlet/pssenat/historie?action=detail \&value $=4732$ 
tedy odborných předmětů na středních odborných školách) osobě, která dosud nezískala odbornou kvalifikaci, splňuje ale podmínku požadovaného stupně vzdělání. ${ }^{5}$ Ve zdůvodnění této radikální změny se slibuje, že všechny osoby, jimž ředitel školy uzná předpoklad odborné kvalifikace, budou moci prímou pedagogickou činnost vykonávat nejdéle po dobu tř́ let. Aby mohly i nadále tyto osoby pokračovat ve vykonávání učitelské profese, musí si doplnit pedagogické vzdělání, a to bud' v programu celoživotního vzdělávání vysoké školy, tzv. DPS, anebo nově tzv. studiem pedagogiky, které mohou nabízet další poskytovatelé vzdělávání. MŠMT deklaruje, že „návrh novely má za cíl otevrít vstup do profese učitele také kandidátuim, kteři prošli odbornou prípravou v jiných oblastech vzdèláváni a u nichž rèeditelé škol v prüběhu jejich započaté praxe shleda$j i$ že jsou pro povoláni učitele vhodni".

Ministr školství R. Plaga při svém vystoupení ve Sněmovně 28. ledna 2020 zevrubně představil vládní návrh zákona. ${ }^{6} \mathrm{~S}$ oporou o výsledky mimořádného šetření ke stavu učitelského sboru v regionálním školství, ${ }^{7}$ které MŠMT zadalo začátkem roku 2019, zdůraznil dva hlavní důvody pro zmírnění kvalifikačních požadavků. Zaprvé průměrný věk učitelů v regionálním školství (47,2 let), zadruhé množství učitelů, kteří podle zákona nesplňují kvalifikační požadavky $(6,5 \%$ výuky je zabezpečováno pracovníky bez potřebného pedagogického vzdělání, kteř́ jsou ve školách tzv. na výjimku). Slovy z projevu ministra: „... tvárí v tvár stárnuti učitelského sboru a zhoršsujici se situaci je vhodné rediteliom otevrít sekundárni $k a-$ nál... To znamená, že když někdo chce učit, tak se ten reditel podivá a vyhodnoti si, jestli ho tam potrebuje a jestli vưbec ten člověk má ten potenciál“. Na jiném místě zmiňuje, že $\mathrm{v}$ počtu nekvalifikovaných učitelů jsou velké rozdíly mezi kraji (explicitně zmiňuje Karlovarský kraj) i mezi stupni škol a nedostatkovými aprobacemi (uvádí matematiku, fyziku, anglický jazyk, odborné předměty na středních školách).

O rok později (22. ledna 2021) před závěrečným projednáváním novely zákona ve Sněmovně píše ministr dopis předsedům poslaneckých klubů politických stran a hnutí, v němž prezentuje jako hlavní důvody pro předložení novely ${ }^{8}$ opět nedostatek učitelů (poptáváno celkově 6000 úvazků učitelů) a věkový průměr učitelů (47,2 let). Ministr uvádí, že "nejvètši poptávka ze strany reditelù je pak po učitelích odborných predmétù na druhém stupni základnich škol a na střednich

\footnotetext{
5 První verzi úprav v zákoně představilo ministerstvo v květnu 2018. Počítala $s$ tím, že se nepedagogům otevřou pouze odborné předměty či výcvik na středních odborných školách. Plaga později nechal návrh dopracovat, když Unie zaměstnavatelských svazů ČR požadovala, aby se změna týkala i výuky všeobecných předmětů na středních školách a na druhém stupni základních škol (https://www.idnes.cz/zpravy/domaci/novela-zakona-ministerstvo-skolstvi-nepedagogove-zakladni-stredni.A190201_101636_domaci_fort).

${ }^{6}$ https://www.psp.cz/eknih/2017ps/stenprot/040schuz/s040181.htm\#r1

7 https://www.msmt.cz/ministerstvo/novinar/ministerstvo-zjistovalo-stav-ucitelu-v-regionalnim-skolstvi

8 http://www.pedagogicke.info/2021/01/robert-plaga-dopis-predsedum.html
} 
školách... MŠMT dlouhodobě vnimá poptávku zejména střednich škol po zapojeni odborniku z praxe do výuky". Stejně jako při prvním představování návrhu novely zákona ve Sněmovně, tak i v uvedeném dopise ministr zdůrazňuje, že „ubude řediteli administrativa spočivajicí v potřebe dokládat, že škola na volné misto učitele aktivnè hledá učitele, který již splñuje predpoklad odborné kvalifikace".

Při dalším vystoupení $\mathrm{k}$ vládní novele zákona, tentokrát na jednání Senátu 18. března 2021, ministr Plaga opět zdůrazňuje již výše uvedené důvody jejího předložení. Jako hlavní záměr návrhu zákona zdůrazňuje „řešeni nedostatku učitelù, pedagogů. Tohoto cíle chce vláda dosáhnout zvýsenim zapojeni odborniku z praxe do výuky". Tentokrát však ještě doplňuje uváděné argumenty reakcí na kritické připomínky z řad odborné veřejnosti (publikovaná stanoviska a otevřené dopisy zaslané poslancům i senátorům), které se koncentrují na nejproblematičtější část novely $-\$ 9$ a. Sám ministr k obavám kritiků novely rríká: „Já si myslím, že tato novela, prestože mediálnè bývá často interpretována velmi, velmi kontroverznè, pokud dnes povedeme tuto debatu, pevnè vèřim, že na konci uvidite, že kontroverzni tolik neni."

Obhajuje otevření jeho slovy „sekundárního kanálu", který dává řediteli „do rukou nástroj $k$ rízení personálnich kapacit této školy“. Dále vysvětluje: „Není to totiž nahrazeni role pedagogických fakult a fakult vzdèlávajicich učitele v našem systé- mu... Neni to o tom, jak bývá někdy mediálni zkratkou interpretováno, že je devalvováno studium na pedagogických fakultách... Tedy neni to devalvace, je to prínos ke stávajicí situaci. "V závěru svého vystoupení ještě uvádí, že MŠMT se ztotožňuje s některými pozměňovacímu návrhy $\mathrm{k}$ vládnímu návrhu novely, které přijala Sněmovna. Ve vztahu ke kvalifikačním požadavkům explicitně zmiňuje dva: (1) návrh umožňující řediteli školy, aby uznal kvalifikaci absolventovi bakalářského studia v oblasti pedagogických věd, který je současně studentem navazujícího magisterského studijního programu zaměřeného na přípravu učitelů všeobecně vzdělávacích předmětů druhého stupně základní školy nebo střední školy, a (2) doplnění studia pedagogiky (120 hodin) do $\$ 9$ a a úprava $\$ 22$ jako jednoho ze společných způsobů získání odborné kvalifikace učitelů - nově tedy i pro učitele 2 . stupně základní školy a učitele všeobecně vzdělávacích předmětů střední školy.

\section{Politici Poslanecké sněmovny Parlamentu ČR}

V návaznosti na stručný přehled klíčových dat projednávání návrhu novely zákona ve Sněmovně ${ }^{10}$ (na s. 6) budou nyní prezentovány výsledky analýzy stenozáznamů z průběhu jednání v období od 7. června 2019 až do zahájení projednávání vráceného návrhu zákona ze Senátu 13. dubna 2021 (aktuálně je projednávání přerušeno). Zaměříme se na stanoviska

\footnotetext{
https://www.senat.cz/xqw/xervlet/pssenat/hlasovani?action=steno\&O=13\&IS=6676\&D=18.03.2021\#b21854 ${ }^{10} \mathrm{https} / /$ www.psp.cz/sqw/historie.sqw?o=8\&t=503
} 
poslanců $\mathrm{k}$ těm částem novely, které se týkají kvalifikačních požadavků na učitele, zejména $s$ důrazem na zdůvodňování jejich (ne)potřebnosti, a také na přijaté pozměňovací návrhy k vládní novele.

Při prvním čtení vystoupilo 13 poslanců ze všech politických stran a hnutí a většina $\mathrm{z}$ nich návrh novely podpořila. Většina jejich vyjádření se týká otevření učitelské profese vysokoškolákům bez pedagogického vzdělání, které by umožnil $\$ 9$ a. Nejčastěji uváděným důvodem byl opět nedostatek kvalifikovaných učitelů, přičemž někteří poslanci zmiňují střední odborné školy, které potřebují odborníky z praxe. Je to např. T. Hythová (SPD) nebo F. Vácha (TOP 09), který ř́ká: „Ten zákon se netýká základniho školství. Ten se týká pouze středního školstvi odborného, odborných predmétù. "I z výpovědí jiných politiků je zřejmé, že si neuvědomují zásadní rozšíření možnosti působení osob bez učitelské kvalifikace i ve výuce všeobecně vzdělávacích předmětů na 2 . stupni základních škol a na jiných středních školách než s odborným zaměřením.

Kromě jednoznačné podpory klubů ANO, TOP 09 a SPD výrazně podpořil vládní návrh, včetně $\$ 9 \mathrm{a}$, také $\mathrm{M}$. Baxa za klub ODS. Zmiňuje zejména nedostatkové obory (přírodní vědy, matematika, informatika) a regiony $s$ tím, že jde o údaje alarmující a že „v tuto chvíli vlastně nemáme žádnou jinou cestu" než zmírnění kvalifikačních požadavků pro vstup do profese. Někteří poslanci vyzdvihují zvýšení odpovědnosti ředitelů za perso- nální zajištění výuky, např. slovy K. Raise (ANO) „docházi $k$ posilení role reditele coby manažera, a to jsme vždycky chtěli". Nejvýrazněji podporují návrh novely a zejména otevření profese lidem bez pedagogického vzdělání Piráti, ${ }^{11}$ jejichž stanovisko prezentuje L. Bartoň: „My tento návrh podporujeme, naopak si myslime, že by ty podminky mohly být ještě volnèjš́, než jak jsou navrženy, ale chápu ten tlak z pedagogických fakult a $z$ oboru zabývajicich se pedagogikou."

Piráti dokonce ve druhém čtení navrhovali, aby ředitel mohl uznat kvalifikaci učiteli (i bez vysokoškolského vzdělání!), který na druhém stupni základní školy nebo na střední škole vykonával prímou pedagogickou činnost po dobu nejméně 10 let, $\mathrm{z}$ toho nejméně pět let souvisle na dané škole. Paradoxně se v této souvislosti L. Bartoň ohrazuje proti „tvrzeni, že pouštime do školstvi kohokoliv a nastane néjaká apokalypsa. Ti lidé tam jsou již nyni. Máme nouzi o ucitele a mnozi reditelé berou kohokoliv, kdo jde okolo, jenom že je mu osmnáct, a prostè potřebujeme tam odborniky ze školstvi."“

Přesto i poslanci podporující snížení kvalifikačních požadavků na učitele zdůrazňují nutnost diskuse o míře potřebné restrikce v oblasti institucí, které budou disponovat právem poskytovat další vzdělávání pedagogům, a tedy i kvalifikační studium „nepedagogům“. Někteří vyjadřují v tomto ohledu obavy, např. K. Rais (ANO): „... mám jakési osobni zkušenosti $z$ minulého vysokoškolského zákona, kdy

$\overline{{ }^{11}}$ https://www.piratskelisty.cz/clanek-3725-stanovisko-piratu-k-novele-zakona-o-pedagogickych-pracovnicich 
jsme prostě povolili v podstatě chod $M B A$ a tady těch zahraničnich studijnich programu bez akreditaci viceméné, a výsledek tedy je, že kdejaké eseróćko z Horni Dolni to dèlá. Takže si myslím, že bychom mèli diskutovat o problematice akreditace dalšiho vzdèláváni pedagogických pracovnikü, aby to nebylo úplnè hozené do vzduchu, aby se toho chytil kdejaký, já nevím, prostě nějaký člověk nebo firma, kterým jde jenom o zisk, ale že nám musí jit taky o tu kvalitu."

Podobný názor sdílí i F. Vácha (TOP 09): „... já se stejně jako kolega Rais obávám toho, že plno instituci nebo rüzných skupin bude pripravovat dalši vzděláváni pedagogických pracovniki a bude to pro nè jenom zisk, budou to délat jenom kvi̊li zisku, a ne kvi̊li tomu, aby dále vzdélávali pedagogické pracovníky. A obávám se, že $k$ tomuto to sklouzne."

Opakovaně vystoupili proti novele zejména J. Mihola (KDU-ČSL) a A. Staněk (ČSSD), kteří varovali, že "návrh tohoto zákona otevírá Pandoŕinu skríňku... jde o nebezpečnou a zákeŕnou devastaci učitelské profese“. Připomínají, že "preded zhruba čtyrrmi nebo pèti lety... tehdejši vládni koalice prosadila ve Snèmovnè, že učitel musi být kvalifikovaný, to znamená musi mit vysokoškolské vzděláni pedagogického smèru. ... dvè strany prédchozi vládní koalice (ANO a ČSSD - doplnila V.S.) jsou ve vládni koalici i dnes. ... A já truám na tom, že úplně nejhorši pro české školství jsou ty neustálé zmèny. Tak v jednu chvili se usneseme, že učitel musi být kvalifikovaný, po pár letech prijideme na to, že to vlastně tak duiležité neni. "Považují návrh novely za zbytečný, nebot „i dnes má reditel mož- nost vzit nekvalifikovaného učitele a také se to dèje“.

J. Mihola poukazuje na západoevropské trendy akcentující odbornou kvalifikaci a pedagogické vzdělání. Říká: „Nedostatek učitelú je i jinde. I v sousednim Rakousku chybi ucitelé. I v Nëmecku... Neni to jenom český problém. "Varuje před "specificky českou cestou" v podobě rezignace na kvalifikační požadavky: „Při srovnáni s evropskými trendy se mi to zdá opravdu jako neodưvodnéný krok zpátky."

Upozorňuje dále na zvýšené požadavky na učitele spojené s inkluzí, která vyžaduje kvalitní pedagogicko-psychologické vzdělání. Polemizuje $s$ oprávněností přenést odpovědnost za přiznání kvalifikace ze strany státu do rukou ředitele: „Nevěr me tomu, že i zkušený reditel rozumi úplně všemu a že každého zrentgenuje pouhým pohledem a rozpozná - tak jednoduché to opravdu neni. Navic dneska je reditel často opravdu víc manažer než pedagog. "Rezervovaně se $\mathrm{k}$ návrhu novely vyjadřovala i K. Valachová (ČSSD), která varovala před nezamýšlenými důsledky legislativní úpravy v podobě vytvoření „paralelního systému“.

Ve druhém čtení byly projednávány pozměňovací návrhy. Nejaktivnějšími v jejich předkládání byli Piráti, zejména zpravodaj garančního výboru L. Bartoň. Kromě navýšení platů se zaměřili především na návrhy týkající se snižování kvalifikačních požadavků na učitele. Dva jejich přijaté návrhy (1) radikálně prolamují dosud nezpochybňovanou magisterskou úroveň vzdělávání (ředitel bude moci škrtem pera uznat za určitých podmínek kva- 
lifikaci učitele bakaláři) a (2) umožňují absolventům neučitelských magisterských oborů doplnit si učitelskou kvalifikaci tzv. studiem pedagogiky (120 hodin, dříve určené mistrům odborného výcviku), které se otevírá širokému spektru poskytovatelů, tedy i komerčním firmám, neziskovým organizacím aj. Rezignace na kontrolu státu $\mathrm{v}$ této věci je zásadním průlomem $\mathrm{v}$ garanci kvality učitelů a jejich připravenosti na učitelskou profesi, která je podle stávající úpravy stále považována za regulovanou profesi. Jak bylo uvedeno výše, řada poslanců, dokonce i podporovatelů novely (např. K. Rais - ANO, F. Vácha - TOP 09), je vůči otevření trhu tomuto segmentu vzdělávání velmi kritická.

Návrhy na zamítnutí návrhu zákona (A. Staněk z ČSSD) a na zrušení $\$ 9$ a ve vládním návrhu (J. Mihola z KDU-ČSL a poté i $A$. Staněk) nebyly přijaty, stejně jako návrh na ještě radikálnější snížení kvalifikačních požadavků, než je v novele (např. u učitelů 1 . stupně ZŠ jako jedna $\mathrm{z}$ cest $\mathrm{k}$ profesi absolvování vyššího odborného vzdělání, předloženo $\mathrm{V}$. Klausem Trikolóra).

Ve třetím čtení novely došlo k poměrně výrazné názorové proměně, zejména v klubech koaličního partnera ČSSD a vládu tolerující KSČM. Svůj vliv nepochybně hrála rozsáhlá kritika de-kvalifikačního a de-profesionalizačního charakteru novely vyjádřeného $\mathrm{v} \$ 9 \mathrm{a}$ ze strany široké pedagogické veřejnosti. Uved'me např. rozsáhle medializovaný protest, ${ }^{12}$ v němž zástupci šesti školských organi- zací, děkani pedagogických fakult a další významné osobnosti českého školství vyzvali společně poslance, aby ve třetím čtení neschválili novelu zákona o pedagogických pracovnících (opět s odkazem na kontroverzní $₫ 9 a)$. V odkazu pod čarou je uveden přehled všech kritických stanovisek od významných reprezentantů odborné veřejnosti zásadně odmítajících novelu zákona anebo požadujících alespoň vypuštění $\$ 9 a$, který lze chápat jako trojského koně „propašovaného“ do novely.

Několik poslanců explicitně zmiňuje publikovaná kritická stanoviska a cituje $\mathrm{z}$ nich vybrané pasáže $s$ tím, že to "nelze prejejit tím, že se jedná o nějaký názor, který nemá kvalifikovanou oporu, nebo že se jedná jenom o nějaké dojmy" (M. Baxa ODS). Vytýkají ministrovi, že „neměl ambici ve veřejném prostoru se témto argumentuim postavit a vést o tom opravdu velkou, kvalifikovanou diskusi. Nelze prostè prejit názory téchto odborniku jenom nèjakým mlčenim, nebo možná někde nějakým internim komentárem. Jedná se o tak závažnou novelu, že by mélo jasně zaznit to, z jakých divvodu Ministerstvo školstvi nesoublasi s témito stanovisky, jakým zpuisobem čeli argumentưm tak vážným, jako je treba Asociace pedagogických fakult nebo někteři jednotlivci, kterí jsou autoritami ve svém oboru" (M. Baxa-ODS).

Poslanci formulují nové argumenty polemizující s opodstatněností radikálního snížení kvalifikačních požadavků a s de-profesionalizací učitelství ( $\$ 9$ a říká, že není třeba profesní, učitelské, pedago-

${ }^{12}$ https://www.pedagogicka-komora.cz/2021/01/spolecny-protest-sesti-skolskych.html 
gické vzdělání, stačí znalost vyučovaného oboru). Odvolávají se na nedávno přijatou Strategii 2030+, v níž se v části 3.1 explicitně mluví o ochraně před de-profesionalizací učitelství. Slovy M. Baxy: „Ve Strategii 2030+ se nikde nehovorí o tom, že by mělo být $v$ následujicich letech cilem $v$ českém vzdělávacím systému privádèt do něj ucitele, kteri nemaji $k$ tomu kvalifikaci ziskanou na školách pripravujicich učitele." Návrh novely považuje za „krok, který je $v$ rozporu s touto strategii “. Vyzývá ministra, aby úprava kvalifikačních požadavků byla chápána jako dočasná, jako přechodné řešení. Mimo jiné také proto, že je plná nejasností a problémů. Je napríklad v rozporu se zařazením učitelství mezi regulovaná povolání, což znamená, že je to stát (ne ředitel jedné konkrétní školy), který určuje podmínky vykonávání této profese a garantuje jejich dodržování.

Předmětem kritiky jsou také zmatečné a zavádějící zmínky o odbornících do škol na výuku odborných předmětů. $\mathrm{Na}$ druhém stupni základních škol žádné odborné vyučovací předměty nejsou, jsou tam všeobecně vzdělávací vyučovací předměty. Odborné vyučovací předměty jsou výhradně na středních odborných školách a učilištích a jejich učitelé mají výjimku z kvalifikace v zákoně již nyní.

Objevuje se zpochybňování jednoho z klíčových důvodů novely, za který je považován nedostatek učitelů - je tu řadu let, nijak dramaticky nestoupá, je problémem ve většině vyspělých zemí (žádná z nich to však neřeší tak svérázným způsobem), není plošný, a tedy není důvodem pro plošnou rezignaci na kvalifikační požadavky. Slovy K. Valachové (ČSSD): "Není pravda, že Česká republika na svém celém územi rèsí nějaký skandálni nedostatek kvalifikovaných učiteli a učitelek. Na to jsou tvrdá data, Ministerstvo školství, mládeže a tělovýchovy je má, já je nebudu opakovat, zmiňovala jsem je ve druhém ćteni. Tato tvrdá data ukazuji, že jsou to procenta, opravdu jednotky procent u několika krajů. To samozřejmě neznamená, že bychom se touto situaci nemèli zabývat. Mèli, ale rozhodnè ne tak, že snižime standard kvalifikovanosti a kvality učitelské profese, a tím vzdèláváni našich dèti na celém územi republiky. Naopak bychom méli podporit všechny kroky pro to, aby v jednotlivých regionech tento problém byl odstranèn, at podporou, napríklad dilčimi bonusy a pobidkami, které rada škol dnes dèlá, napríklad podporou zajištèni bydleni, pokud jsou absolventi vzdáleni z jiných regionů..."

Poslanci (např. J. Mihola, K. Valachová) upozorňují také na to, že jednou z klíčových prrícin nedostatku učitelů jsou podmínky $\mathrm{k}$ vykonávání profese, zejména až nedůstojná výše platů, která řadu učitelů vyhnala $\mathrm{z}$ profese a absolventy učitelského studia odrazuje od vstupu do praxe (navíc data ukazují, že se úspěšně uplatní v jiných profesích a jsou žádaní na trhu práce). Dá se předpokládat, že současný pozitivní trend ve zvyšování platů přinese obrat.

Poměrně kritická diskuse $\mathrm{v}$ rámci třetího čtení vyústila $\mathrm{v}$ rámci rozhodování o pozměňovacích návrzích $\mathrm{v}$ předložení návrhu k zamítnutí zákona. ${ }^{13}$ Hlasová-

${ }^{13}$ https://www.psp.cz/sqw/hlasy.sqw?G=75100 
ní (22. ledna 2021) potvrdilo názorovou proměnu a narušení dosavadní silné podpory novely např́č politickými stranami. Z 99 hlasujících poslanců a poslankyň bylo 17 pro zamítnutí, 63 byli proti a 19 se zdrželo hlasování. Všichni př́tomní poslanci ČSSD a KSČM hlasovali pro zamítnutí, všichni př́tomní poslanci z KDU-ČSL se bud' zdrželi, nebo hlasovali pro zamítnutí. O několik dní později byl však návrh novely při závěrečném hlasování přijat drtivou většinou poslanců.

\section{Politici Senátu Parlamentu ČR}

Návrh zákona byl Senátu postoupen 22. února 2021 jako tisk 53, dokument $53 / 0 .{ }^{14}$ Po projednání garančním výborem byl $s$ doporučením vrátit návrh Sněmovně $s$ pozměňovacím návrhem kosmetického charakteru zařazen na 7 . schůzi Senátu 18. března 2021. Př́i analýze stenozáznamů vystoupení senátorů se zaměříme, stejně jako v prrípadě vyjádření poslanců ve Sněmovně, pouze na stanoviska včetně jejich argumentace $\mathrm{k}$ těm částem novely, které se týkají kvalifikačních požadavků na učitele. Prakticky všechna vystoupení senátorů byla z podstatné části věnována právě této otázce. Akcent na tuto problematiku nepochybně souvisel $s$ tím, že podle vyjádření samotných senátorů „byli bombardováni různými nesoublasnými stanovisky pedagogických fakult a dalšich pedagogických instituci oblednè I $9 a^{\prime \prime}$ e-maily, ve kterých se objevovala slova "degradace, tragédie, apokalypsa, trojský kưn“" $\mathrm{v}$ souvislosti s touto kvalifikační novinkou.
S podrobným vyjádřením vystoupil zpravodaj garančního výboru a jeden $\mathrm{z}$ nejhorlivějších podporovatelů novely J. Drahoš (Starostové a nezávislí), podle jehož názoru je novela ,jednim z nejvýznamnějsich legislativnich kroku $v$ oblasti vzděláváni $v$ tomto volebnim obdobi“. Zdůrazňuje, že "dìležitým cílem je pootevrít profesi odbornikuim bez pedagogického vzdèláni. Tedy to, o co se jedná v tom diskutovaném $\mathbb{S} 9 a^{“}$. Opírá se, stejně jako další senátoři podporující otevření učitelské profese, o víru, že „tento krok priláká do školstvi radu kvalitnich lidi, kteři by jinak nikdy učit nešli“.

Toto přesvědčení vychází z individuálních prríkladů lidí, většinou ředitelů škol (J. Drahoš např. často zmiňuje svého kolegu v Senátu J. Růžičku), kteří „ve svých učitelských sborech méli prvotrídni učitele, kterí nemèli príslušné pedagogické minimum“. Podobné př́ípady však nezpochybňují ani odpůrci novely z řad senátorů, kteří však zdůrazňují, že je nelze generalizovat a dělat z výjimek pravidlo, systém. V obdobné logice pokračuje J. Drahoš tentokrát obecným tvrzením, proti kterému rovněž nelze nic namítat, že „studium na pedagogické fakultè automaticky z nikoho neudèlá ani kvalitního učitele, ani kvalitniho člověka. V té souvislosti pripominám, že $i$ pan poslanec Volný je absolventem pedagogické fakulty. "Podobnými konkrétními př́klady „špatných“ absolventů pedagogických fakult a „vynikajících “ učitelů bez pedagogického vzdělání $\mathrm{z}$ těchto fakult

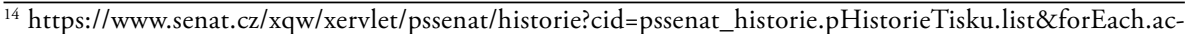
tion $=$ detail \&forEach.value $=s 4732$
} 
argumentují i další senátoři. Používají je v rámci ostré kritiky práce pedagogických fakult, přičemž současně řada senátorů s pedagogickým vzděláním zdůrazňuje, že ho získali na jiné fakultě vzdělávající učitele, na filozofické, prrírodovědecké apod.

Kritika pedagogických fakult a potřeba vytvoření konkurence pro ně zaznívají $\mathrm{z}$ úst více senátorů, u některých jako jeden $\mathrm{z}$ hlavních motivů pro prijietí novely. $\mathrm{V}$ podání M. Canova (STAN): „A taky se budou muset snažit, pedagogické fakulty. Holt když ředitel bude moci dát prednost někomu zvenči. Ale at dává. Ted'spousta učitelù odcházi i jinam, na novinařinu tře$b a$. Tak at' je to taky opačnè, at lidi zvenku chodi na mista uciteliu. Myslim, že se tím nic nezkazi."

Senátoři podporující novelu považují za zásadní důvody, podobně jako poslanci, převážně „tragický“ nedostatek učitelů, vysoký průměrný věk učitelského sboru, nízký podíl absolventů učitelských oborů vstupujících do školní praxe (kolem $50 \%$ ), odchody učitelů z profese včetně začínajících učitelů, posílení pravomoci ředitelů jako manažerů odpovědných za kvalitu vzdělávání a potřebu konkurence pro pedagogické fakulty.

V Senátu však vystoupili také politici napříc politickými stranami s kritickým postojem vůči novele $s$ tím, že ji někteří nepodpoří. Byli to zejména předseda Senátu M. Vystrčil (ODS), J. Grulich (TOP 09 a ODS), J. Větrovský (PROREGION) a T. Třetina (ODS a TOP 09). Zásadně nesouhlasí se záměrem „otevrít školy nepedagogům... tak daleko jsme to tedy dotábli“ (J. Grulich). Vysvětlují proč, v čem spočívá odbornost, profesionalita a kvalita učitele. Znalost oboru, obsahu, který má učitel žákům zprostředkovat, tvoří jen jednu část jeho odbornosti, jen jeden předpoklad kvalifikace. Kritizují, že zákon nerespektuje rozdíly mezi učitelem střední školy (zejména střední odborné školy) a učitelem na druhém stupni základní školy. Slovy J. Větrovského: "Já si myslim, že tady jde o dvě úplně rozdilná povolání... o úplně jiný typ vyučování, úplně jiný typ pedagogické ćinnosti než na středni odborné škole“. Tento senátor avizuje, že předloží „pozménovaci návrh, kde by tedy $\mathbb{S} 9 a$, ten mýtický paragraf, byl vypuštèn".

$S$ tímto názorem souhlasí další senátoři, např. M. Adámek (PROREGION) a T. Třetina, který dokonce považuje otevření učitelské profese na 2 . stupni základních škol „neaprobovaným bez patričného pedagogického vzděláni za extrémni krok". I podporovatel novely J. Růžička (Starostové a nezávislí) uznává, že „je rozdíl mezi základni školou, 2. stupném a středni školou", přičemž připouští, že na potřebu otevření profese odborníkům nahlíží z perspektivy situace na středních školách (v jeho prrípadě je ve hře také optika úspěšného ředitele gymnázia).

S obsáhlým proslovem vystupuje předseda Senátu M. Vystrčíl ${ }^{15}$ a v jeho úvodu konstatuje, že "v posledni době hrozi školstvi takové tři rány, které obdrži a které jen

\footnotetext{
15 Vystrčil, M. Systém nevede k tomu, že se zvýší kvalita výuky. Pedagogické info. (Online). Dostupné z https:// www.pedagogicke.info/2021/03/milos-vystrcil-system-nevede-k-tomu-ze.html?fbclid=IwAR1pMlyqW5Uwx1ZkwzoGTs6dDObFNgP-rYwFd3eXsfTeYubSn7NURMINONU
} 
velmi obtižně bude zvládat". Jako jednu z nich uvádí „zákon o pedagogických pracovnicich a ten oslavovaný $\mathbb{S} 9 a^{“}$. Dodává, že je jeho odpůrce. Polemizuje s nejfrekventovanějším tvrzením o nedostatku učitelů jako hlavním důvodem pro otevření profese. Označuje ho jako „mýtus. Máme málo učitelì. My nemáme málo učitelü, my máme málo učiteli ve školách. ... My je nechceme vrátit do škol, ty, co neuči. My chceme najit jiné, co nestudovali pedagogické fakulty, a dostat je do škol. Tèch $50 \%$, co neuči a mobli by učit, necháme být a nijak speciálnè se na ně nezamérujeme. Ale my je tady máme, oni maji vystudováno." Upozorňuje na stav, který by bylo možné cílenými intervencemi vzdělávací politiky ovlivnit a přispět tak $\mathrm{k}$ řešení, zmírnění problému.

M. Vystrčil také důrazně připomíná, že učitelství je regulované povolání ze zákona, uvádí na příkladech jiných profesí, co to obnáší, a ptá se: „To jsme v nějaké volné soutěži v prípadě výuky? Jestli jsme, tak to potom musi být všechno soukromé školstvi a nemůžeme mit státni školství a nemůžeme mít garantovaný systém vzdělávací.. Jinak to takble nejde. Nerozumím tomu a nemohu se s timto smirit. "Pozastavuje se také nad tím, že by jedním ze zásadních důvodů (byt se o tom explicitně nemluví) $\mathrm{k}$ otevření profese lidem bez pedagogického vzdělávání, k uznání učitelské kvalifikace ředitelem školy mohla být nespokojenost $s$ pedagogickými fakultami, s kvalitou jejích absolventů. „Řikáme, že pedagogické fakulty nedostatečnè nebo nesprávnè vzdèlávají."To ale „nemuiže být divvod $k$ rezignaci na pedagogické vzdèlávání... To je cesta do pekel."
Senátor M. Bek (Starostové a nezávislí), bývalý rektor Masarykovy univerzity, stejně jako M. Vystrčil zdůrazňuje, že MŠMT v roce 2016 legislativně zakotvilo, že „učitelství, stejně jako medicína, bude regulovanou profesi ve smyslu zákona a ministerstvo školstvi bude uznávaci autoritou, která bude regulovat to, jak vypadaji učitelské studijni programy... Na jedné stranè ted' tato novela ríká s jistou nadsázkou, že ke vstupu do té profese neni třeba ničeho, zatímco chce-li univerzita provozovat program učitelství, musi splnit standard, který predepisuje, kolik hodin, kolik kreditů, kolik rüzných typů predmètů musi ten program obsahovat." Tento zásadní rozpor je obtížně akceptovatelný a je pochopitelně zdrojem velké frustrace fakult připravujících učitele. V obecnějším smyslu se podivuje nad "mesianistickými utopiemi, které predpokládaji, že tím jednim paragrafem vstoupi do českého školstvi zástupy neopotrebovaných, nadšených amatéru, kteři zachráni kvalitu českého školstvi".

M. Bek se přidává také $\mathrm{k}$ hlasům, které zpochybňují údaje o nedostatku učitelů: "O málokteré oblasti víme tak málo, jako je školství, z hlediska spolehlivých statistik. Neexistuje matrika žákư, neexistuje matrika učitelì, občas se konaji nějaké priokkumy, ve kterých reditelé referuji o tom, jaké maji složeni ucitelstva, ale na rozdil od vysokých škol neexistuje žádná spolehlivá statistika, která by umožñovala analyzovat, jak vypadá učitelský sbor z hlediska kvalifikace, věku, délky, zkušenosti a dalšich parametrü. Celá ta debata preci jenom je založena na relativně mèkkých datech. Nepochybnè existuji velké regionálni rozdily, které jsou 
možná tím, co nás páli nejvíc. To je velmi podobná situace jako u mediciny. " Připomíná v této souvislosti návrhy, které byly $\mathrm{v}$ minulosti předkládány ministerstvủm zdravotnictví i školství (např. vytvoření stipendijního systému či jiné motivační pobídky), na které však politici nereflektovali.

Kritici novely, zejména kontroverzního $₫ 9$ a, se pokusili o jeho vypuštění z novely. Podali pozměňovací návrh (J. Větrovský, P. Vícha), který byl zamítnut. Výsledek hlasování - z 65 hlasujících senátorů bylo devět pro zamítnutí (čtyři z ODS, čtyři z PROREGION, jeden nezařazený), 24 byli proti a 32 se zdrželi hlasování - ukázal pochybnosti části senátorů (mimo jiné i vysoký počet těch, kteří se hlasování zdrželi).

\section{Další aktéři}

Postoje odborné veřejnosti $\mathrm{k}$ de-kvalifikační a de-profesionalizační novele jsou silně polarizované. Proti novele vystupují jak zástupci profesních asociací, spolků, školských odborů, tak významné osobnosti v oblasti vzdělávání. ${ }^{16}$ Devět školských organizací společně formuluje otevřený dopis před projednáváním novely v Senátu - Výzva zástupců deviti školských organizaci a dalšich predstavitelu učitelské profese Senátu. ${ }^{17}$ Pod výzvou jsou podepsáni: Česká pedagogická společnost, Jednota českých matematiků a fyziků, Asociace děkanů pedagogických fakult ( $\mathrm{k}$ nim se přidávají i děkani několika filozofických fakult), Pedagogická komora, Českomoravský odborový svaz pracovníků školství, Asociace češtinářů, Asociace učitelů angličtiny ČR, Asociace pracovníkủ speciálně pedagogických center.

Signatári výzvy hodnotí novelu jako velmi nebezpečnou, žádají její úpravu, zejména vypuštění kontroverzního $\$ 9 \mathrm{a}$ odst. 1. Zpochybňují deklarované důvody pro plošné snížení kvalifikačních požadavků - zejména "údajnè kritický nedostatek kvalifikovaných učiteliu“, potřebu zkvalitnit výuku ve školách odborníky z praxe a nutnost posílit pravomoci ředitelů škol v personální oblasti. S oporou o data argumentují, že "nedostatek není plošný ani katastrofický" - v absolutních číslech jde celkem o maximálně o 1600 až 2000 nekvalifikovaných učitelů, kteří si kvalifikaci nedoplňují, a je výhradně regionální (v Karlovarském kraji je nekvalifikovaných úvazků téměr jedna pětina

$\overline{16}$ Kol. autorů. (2021). Nedostatek kvalifikovaných učitelů nelze řešit rezignací na kvalifikaci. Pedagogika, 71(1), 120-125.

Spilková, V. (17. 1. 2021). Otevřený dopis poslancům k novele zákona o pedagogických pracovnících. Pedagogické info. (Online). Dostupné z https://www.pedagogicke.info/2021/01/vladimira-spilkova-otevrenydopis.html? showComment $=1610897747004$

Jedním z nejaktivnějších odpůrců novely v mediálním prostoru byl bývalý ministr školství $S$. Štech, např. https://denikreferendum.cz/clanek/32201-reakcni-novela-zakona-o-pedagogickych-pracovnicich

Štech, S. (19. 1. 2021). Dopis poslancům školského výboru PSP ČR k novele zákona o pedagogických pracovnících. Pedagogické info. (Online). Dostupné z http://www.pedagogicke.info/2021/01/stanislav-stechdopis-poslanci.html?q=stanislav $+\% \mathrm{C} 5 \% \mathrm{~A} 1$ tech

17 http://www.pedagogicke.info/2021/03/vyzva-zastupcu-deviti-skolskych.html 
a kvalifikaci si zde nedoplňuje $8 \%$, v osmi krajích jde pouze o zlomky jednoho procenta nebo maximálně o $2 \%$ nekvalifikovaných).

Předmětem kritiky je také „bezdůvodné rozšîréení působení odborníků ve školách“. Od dosavadní výuky odborných předmětů na středních odborných školách $\mathrm{k}$ výuce všeobecně vzdělávacích předmětů na 2. stupni základní školy a na gymnáziích. A v neposlední řadě $\mathrm{i}$ „bezprecedentní rozšíreni pravomoci réditelï“ škol udělovat profesní kvalifikaci škrtem pera.

$\mathrm{K}$ přenesení odpovědnosti za kvalitu učitelů ze strany státu na ředitele se staví kriticky, pro mnohé možná překvapivě, nezisková organizace Učitel naživo ve svém vyjádření ${ }^{18} \mathrm{k}$ tématu kvalifikací a jejich legislativního ukotvení: „Stát má nést odpovédnost za kvalitu učitelü. Má povinnost kvalitu (profesionalitu) vyžadovat/vymáhat pri vstupu do profese. Rezignovat na tuto snahu (tzn. neklást na vstup do učitelské profese žádné požadavky nebo tyto požadavky $v$ rozporu $s$ mezinárodnimi trendy snižovat), nese z této perspektivy významné riziko sniženi úrovnè nastupujicich učitelü. Proto je stát zodpovédný za vytvořeni a provozováni účinného nástroje, regulujicího kvalitu v profesi.“

Opačný postoj $\mathrm{k}$ novele, i $\mathrm{k}$ onomu „mýtickému“ $\$ 9$ a odst. 1, zaujímají zejména Učitelská platforma, Unie školských asociací CZESHA, Asociace ředite- lů základních škol, Sdružení učňovských zařízení, z neziskových organizací ji hlasitě podporuje EDUin. Rezervovanější přístup zastává Asociace ředitelů gymnázií, jejíž předsedkyně R. Schejbalová rríká: „Já príliš nejásám, ale na druhou stranu je třeba ríct, že to legalizuje současný stav, protože kolikrát jsme $v$ takové tísni, že takového zamèstnance (bez pedagogického vzdèláni) prijmout musime."

Nejsilněji a dlouhodobě se veřejně angažovala $\mathrm{v}$ „boji“ za otevření učitelské profese nezisková organizace EDUin. Když v květnu 2018 MŠMT představilo první verzi úprav v zákoně, počítalo v něm s tím, že se „nepedagogům“ otevře pouze výuka odborných předmětů či výcvik na středních odborných školách. ${ }^{19}$ EDUin téměř okamžitě přispěchal $s$ tiskovou zprávou, ${ }^{20} \mathrm{v}$ jejímž úvodu konstatuje: „Zámèr MŠMT rozšírit kvalifikačni predpoklady pro vstup do učitelské profese pouze ve prospěch učitelì odborného výcviku (mistrü) na ucilištich a strednich odborných školách je nedostatečný. Okolnosti vyžaduji rozšireni možnosti vstupu do učitelské kvalifikace pro všechny stupně škol a jejich zaméreni." EDUin v tiskové zprávě požaduje "uvolněni pedagogické profese pro všechny absolventy VŠ'. A analytik EDUinu B. Kartous k tomu dodává: "Na nutnost rozširitit možnosti vstupu do pedagogické profese upozorñujeme každoroč-

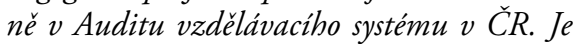
nepochopitelné, že ministerstvo školstvi stále

\footnotetext{
${ }^{18}$ https://www.ucitelnazivo.cz/blog/vyjadreni-stat-ma-zajistovat-aby-bylo-ucitelu-dostatek-a-aby-byli-kvalitni ${ }^{19} \mathrm{https} / /$ www.idnes.cz/zpravy/domaci/novela-zakona-ministerstvo-skolstvi-nepedagogove-zakladnistredni.A190201_101636_domaci_fort

${ }^{20} \mathrm{https} / /$ eduin.cz/tiskove-zpravy/tiskova-zprava-je-nutne-uvolnit-ucitelskou-profesi-vs-vzdelanym/
} 
podléhá tlaku zájmových skupin reprezentujicich dnešni profesni skupiny v českém školství..." EDUin byl také $\mathrm{v}$ této věci velmi aktivní v mediálním prostoru, zejména prostřednictvím novináře T. Feřteka.

\section{DisKuSE VÝSLEDKŮ VÝZKUMU}

Výzkumná data umožnila vhled do realizace vzdělávací politiky na prýkladu legislativního procesu spojeného $s$ projednáváním novely zákona č. 563/2004 Sb., o pedagogických pracovnících, která obsahuje zásadní snížení kvalifikačních požadavků na učitele před vstupem do profese. Přinesla řadu zjišstění, která pomohla v hledání odpovědí na výzkumné otázky. Analýza diskusí ve Sněmovně a Senátu ukázala, že za jádro novely považují politici otevření profese vysokoškolsky vzdělaným odborníkům bez pedagogického vzdělání, nebot většina jejich promluv se týkala $\$ 9$ a a jeho zdůvodňování. Za zásadní důvody pro novelu považuje většina poslanců a senátorů (1) nedostatek kvalifikovaných učitelů, (2) průměrný vysoký věk učitelského sboru, (3) nízký podíl absolventů učitelských oborů vstupujících do školní praxe (kolem $50 \%$ a (4) posílení role ředitele a jeho odpovědnosti v personální oblasti.

Zaměříme se nyní na korektnost a relevanci argumentů, kterými politici zdůvodňovali zásadní snížení kvalifikačních požadavků na učitele. $S$ oporou o rele- vantní data a s využitím publikovaných kritických stanovisek různých aktérů (včetně vlastních článků a otevřených dopisů poslancům a senátorům) zpochybňujeme nejčastěji oficiálně prezentované důvody pro tento radikální krok:

(1) Nedostatek kvalifikovaných učitelů není plošný, je regionální (existují velké rozdíly mezi regiony) a oborový (týká se několika oborů). ${ }^{21}$ Není tragický, katastrofický (jak se vyjadřovali někteří politici), nijak dramaticky neroste, je obdobný jako ve většině vyspělých zemí. Také řada politiků v Senátu i Sněmovně např́íc politickými stranami zpochybnila údaje o nedostatku učitelů s tím, že neexistují spolehlivé statistiky, že jde o „měkká“ data (MŠMT se opíralo o šetření z roku 2019 založené na ad hoc informacích od ředitelů škol více než třetina chybějících úvazků se ale týkala učitelů mateřských škol a 1 . stupně ZŠ). Zdůrazňujeme také fakt, že odhad, ze kterého vychází ministerstvo, ignoruje úbytek žáků nastupujících do základních škol, nárůst počtu učitelů díky zvýšení platů, sílící trend návratů kvalifikovaných učitelů z mimoškolní sféry a celkovou situaci na trhu práce kvůli covidu-19.

Kriticky se $\mathrm{k}$ hodnotě použitých dat MŠMT vyjadřovali např. M. Bek, K. Valachová, M. Vystrčil, který dokonce označuje nedostatek učitelů za „mýtus“, a řada dalších. Relevanci tohoto nejčastěji uváděného důvodu zpochybňuje i podporovatel novely J. Růžička: „Nemohu soublasit ani

\footnotetext{
${ }_{21}$ Koucký, J. (2021). Učitelů možná není vưbec málo. Dostupné z https://vzdelavani21.cz/V21-21.html?news $=12163 \&$ locale=cz. Koucký, J. (2020). Di̊vody nedostatku učitelu․ Úvodní studie z projektu. Dostupné z https://pages.pedf.cuni.cz/nedostatekucitelu/author/24625498/
} 
s panem ministrem, ani s panem profesorem Drahošem, že touble zmènou zákona réšme předevšim nedostatek učitelì, který existuje. To by bylo málo a bylo by to velice smutné, protože na to by mél mit stát pravděpodobně úplně jiné nástroje, jiné páky. At’už to je plat nebo at' to jsou podminky, at to jsou počty dètí ve trídách a tak dále."

Z hlediska mezinárodního srovnání stojí za pozornost fakt, že podle komparativních dat ${ }^{22}$ čelí problému nedostatku učitelů 35 vzdělávacích systémů napříc Evropou. Většina $\mathrm{z}$ nich i za této situace nemá alternativní cesty $\mathrm{k}$ učitelské profesi (alternativní cestou, kterou disponuje třetina zemí, se však $\mathrm{v}$ žádném př́ípadě nemyslí „uděleni“ kvalifikace bez splnění zákonných požadavků).

(2) Relevantní zahraniční zdroje $e^{23}$ zpochybňují další zdůrazňovaný a medializovaný důvod $\mathrm{k}$ otevření profese - stárnutí učitelských sborů. Jako by šlo o něco specificky českého, mimořádného v mezinárodním srovnání. Jaká jsou však fakta? S odkazem na nejnovější publikaci z roku $2021-\mathrm{v}$ počtu učitelů nad 50 let jsme na tom dokonce lépe, než je průměr zemí EU (ČR 36,7\%, EU 38 \%). Řada dalších zemí čelí vážnějším problémům a nepřistupuje $\mathrm{k}$ tak radikálnímu řešení, jako je rezignace na kvalifikační požadavky (např. Německo 44\%, Itálie 50,3\%, Recko 53,7\%, Portugalsko 46,7 \%).
(3) Poslední rozsáhlý celostátní výzkum uplatnění absolventů českých vysokých škol z konce roku 2018 ukázal, že dvě třetiny absolventů učitelských programů a oborů nastupují do školství. ${ }^{24} \mathrm{Ab}-$ solventi pedagogických oborů nastupující do odpovídajícího povolání dokonce převyšují průměr všech absolventů vysokých škol s výjimkou absolventů zdravotnických oborů a informačních a komunikačních technologií.

(4) Jako hlavní argument pro podporu přenesení pravomoci státu udělovat kvalifikaci učitelům na ředitele konkrétní školy je použit $\$ 164$ školského zákona, podle kterého je za kvalitu vzdělávání odpovědný ředitel školy. Odpovědnost ředitele je velká, ne však výlučná. ${ }^{25}$ Vztahuje se především $\mathrm{k}$ rodičům žáků a ke zřizovateli. Garantem veřejného zájmu je však stát, který pomocí politických nástrojů vyvažuje dílčí zájmy různých skupin (žrizovatelů, ředitelů, učitelů, rodičů apod.). Ve věcech veřejného zájmu se nastavují pravidla z hlediska celku. Odpovědnost za kvalitu celého vzdělávacího systému má stát, a tedy má mít i roli garanta zákonných požadavků na kvalifikaci učitelů.

Ve všech vyspělých zemích uděluje profesní kvalifikaci stát, nikoli ředitel školy. U důležitých a uznávaných profesí (tzv. regulovaná povolání, u nichž stát vyžaduje splnění kvalifikačních předpokladů) ani

\footnotetext{
${ }^{22}$ European Commission/EACEA/Eurydice, 2018, 2021.

${ }^{23}$ European Commission/EACEA/Eurydice, 2021.

${ }^{24} \mathrm{https} / /$ vzdelavani21.cz/V21-21.html?news $=12163 \&$ locale $=\mathrm{cz}$

${ }_{25}$ Štech, S. (18. 3 .2021). Stát, nebo ředitel školy? Kdo má odpovědnost za kvalitu školního vzdělávání? Pedagogické info. (Online). Dostupné z http://www.pedagogicke.info/2021/03/stanislav-stech-stat-nebo-reditel-skoly. html?q=Stanislav+\%C5\%A1 tech
} 
nelze uvažovat o jiném potvrzení kvalifikace. O kvalifikaci lékaře rovněž nerozhoduje ředitel nemocnice, který svým podpisem uzná jako chirurga např́iklad zubaře. $\mathrm{Z}$ mezinárodních srovnání a doporučení ${ }^{26}$ (např. OECD 2020: Education at a Glance nebo Eurydice 2018: Teaching Careers in Europe: Access, Progression and Support) jednoznačně vyplývá, že bychom byli jedinou zemí (kromě Estonska), v níž je možné získat učitelskou kvalifikaci rozhodnutím ředitele školy, nikoli splněním kvalifikačních předpokladů. $\mathrm{Na}$ rozdíl od všech ostatních zemí, i těch, v nichž jsou problémy s nedostatkem kvalifikovaných učitelů větší než u nás.

K uvedeným důvodům, kterými se politici snažili legitimizovat své rozhodnutí rezignovat na kvalifikační požadavky (co jiného je možnost uznávání kvalifikace škrtem pera ředitele jedné školy?), si dovolujeme shrnout, že je nelze považovat za zcela korektní a důvěryhodně ospravedlňující tento radikální a v mezinárodním měřítku naprosto ojedinělý krok.

Nepovažujeme-li nejčastěji uváděné důvody pro de-kvalifikační a de-profesionalizační novelu za relevantní a dostatečně opodstatněné, nabízí se spekulativní otázka po dalších důvodech. Jedním $\mathrm{z}$ důvodů, který sice nebyl explicitně uváděn většinou poslanců a senátorů mezi hlavními důvody, ale často byl v různých souvislostech zmiňován a podrobněji rozváděn, je nespokojenost $s$ pedagogickými fakultami, s kvalitou jejích absolventů. Je otázkou, do jaké míry je oprávněná úva- ha, že klíčovým, byt' „zamlčeným“ důvodem pro otevření profese je nespokojenost s pedagogickými fakultami, s kvalitou jejích absolventů. A tedy snaha vytvořit jim konkurenci. Tento záměr je hodně podporován, někdy i iniciován neziskovými organizacemi a různými vzdělávacími agenturami cílícími na rozšíření trhu se vzděláváním. Jejich hlas byl často zesilován médii, a vytvářel tak společně s různými lobbisty tlak na politiky, kteř́ z podstaty věci naslouchají hlasu lidu.

Za pozornost stojí také př́stup MŠMT jako předkladatele novely a jejích nejvýraznějších podporovatelů $\mathrm{z}$ řad politiků ke kritickým názorům oponentů, způsob reakce na jejich odborné argumenty založené na expertní znalosti opřené o relevantní výzkumná data (často z mezinárodní výzkumů a doporučení na evropské úrovni). K řadě argumentů se nevyjadřují, přecházejí je mlčením (což vytýká ministrovi např. poslanec $\mathrm{M}$. Baxa) nebo na ně reagují jako na subjektivní názory a osobní mínění jednotlivců, o kterých prostě jednoduše řeknou, že s nimi nesouhlasí, že se s nimi neztotožňují. Namísto věcných protiargumentů opakovaně prezentují kategorické soudy typu „v žádném prípadě se neztotožňuji. Rozhodně se nejedná o žádné radikálni sniženi kvalifikačnich požadavkì ani o rezignaci státu na kvalitu učitelü (J. Drahoš). Namísto faktů a evidence-based dat se opírají o konkrétní př́klady, př́iběhy z praxe, jednotlivosti vytržené z kontextu typu: „Často slyšim... ředitelé ríkaji: Lidé z praxe, kteři prijdou, maji

${ }_{26}$ OECD: Education at a glance, 2020; European Commission/EACEA/Eurydice, 2018. 
životni zkušenosti taktéž. Jsou na ten druhý stupeň velmi dobře použitelni... Jenom cituji, co jsem ne slyšel, ale co slýchám" (J. Drahoš).

Zjištěná data ukazují dlouhodobý obecný problém české vzdělávací politiky. Při její tvorbě a procesech rozhodování jsou ve velmi nízké míře využívána relevantní data a výzkumně doložená doporučení domácí i zahraniční provenience. ${ }^{27}$ $\mathrm{V}$ některých př́padech jsou víceméně ignorována nebo jsou $s$ nimi $\mathrm{v}$ protikladu, což je př́ípad aktuálně projednávané de-kvalifikační novely. Přitom $\mathrm{v}$ tomto prŕpadě jde zejména o zcela nevyužitý potenciál srovnávací pedagogiky, která plní (zvláště v období transformace a výraznějších změn) důležitou funkci vyhledávací a intervenující (Walterová, 1993, 2006). Obohacuje pohled na vlastní vzdělávací systém (nabízí reflexi domácí situace v mezinárodním kontextu), ukazuje zkušenosti jiných zemí s podobnými problémy a přináší inspirace $\mathrm{k}$ jejich řešení i varování před riziky a opakováním chyb.

Jak bylo uvedeno výše, relevantní mezinárodní zdroje, zejména respektované publikace EURYDICE, ${ }^{28}$ které srovnávají přesně strukturovaná data $\mathrm{z}$ několika desítek evropských zemí, potvrzují, že většina zemí čelí stejným výzvám - nedostatek učitelů a stárnutí učitelských sborů, udržení mladých učitelů v profesi a nedostatek zájemců o učitelské studium. Většina těchto výzev souvisí s tím, že učitelská profese prochází již několik let kri- zí a není dostatečně přitažlivá pro mladé lidi. Tyto problémy nejsou tedy $\mathrm{v}$ žádném př́ípadě specificky české (v některých vyspělých zemích jsou dokonce silnější než u nás), jak bývá politiky i médii mylně prezentováno. Většina zemí volí a ověruje v praxi ne plošná opatření, ale cílené intervence, např. ke zmírnění nedostatku učitelů - zlepšování celkových podmínek pro vykonávání profese, různé incentivy k nalákání studentů do nedostatkových učitelských oborů (stipendia), získání učitelů do určitých regionů finančními stimuly, nabídkou bytů apod. Je evidentní, že česká vzdělávací politika by měla výrazně naslouchat doporučením evropské vzdělávací politiky založeným na kumulativní evidenci z mezinárodních výzkumných dat.

Z druhé strany se nabízí otázka pro český pedagogický výzkum, jak velkou cítí odpovědnost za intervenující roli v ovlivňování vzdělávací politiky, $\mathrm{v}$ jaké míre je ochoten se angažovat při zprostředkovávání porozumění mezi školskou praxí a vzdělávací politikou, nakolik věří ve smysluplnost tohoto angažmá. Je namístě se také ptát, jakým poznatkovým fondem a jakou výzkumnou databází disponuje, $\mathrm{v}$ jaké podobě je školskopolitické decizi nabízí. Jak propracované jsou argumenty, zda jsou srozumitelné pro dané adresáty apod. Výzvou pro pedagogický výzkum je reflektovat limity využití výsledků výzkumu pro vzdělávací politiku, např. jeho fragmentarizaci, nedostatek

\footnotetext{
${ }_{27}$ Štech, S. (27. 1. 2021). Ministrův pomník. Pedagogické info. (Online). Dostupné z http://www.pedagogicke. info/2021/01/stanislav-stech-ministruv-pomnik.html?q=stanislav+\%C5\%A1tech

${ }^{28}$ European Commission/EACEA/Eurydice, 2018, 2021.
} 
syntetických studií a výzkumných dat poskytujících kumulativní evidenci, komplexní charakter řady témat $\mathrm{v}$ učitelství, který vyžaduje interdisciplinární výzkum zahrnující kromě pedeutologických znalostí také poznání v oblasti psychologie, sociologie, vzdělávací politiky, ekonomie aj.

\section{ZÁVĚR}

Studie byla věnována analýze prrístupu české vzdělávací politiky ke kvalifikačním požadavkům na vstup do učitelské profese v aktuálně projednávané novele zákona č. 563/2004 Sb., o pedagogických pracovnících, a jejím kontroverzním $\$ 9$ a odst. 1 . Zaměřily jsme se na zkoumání prezentovaných důvodů pro novelu a obsah i způsob argumentace politiků v průběhu jejího projednávání ve Sněmovně a Senátu. Předmětem pozornosti bylo také posouzení, v jaké míře se politické rozhodování v ČR ve zkoumaném př́padu opírá o relevantní data, teoreticky a výzkumně zdůvodněné názory a doporučení odborníků i o klíčové mezinárodní trendy.

Zasazení aktuální de-profesionalizační a de-kvalifikační novely do kontextu vývoje př́stupů vzdělávací politiky $\mathrm{k}$ učitelské profesi a prrípravě na ni v posledních 25 letech jasně ukazuje, že představuje vyvrcholení permanentního zpochybňování učitelského povolání $\mathrm{v}$ podobě periodicky se opakujících pokusů o snižování kvalifikačních požadavků na učitele. Zcela nevídaný je fakt, že devalvační snahy iniciovalo ve většině př́ípadů samo MŠMT. Těžko si představit, že by se jiné ministerstvo chovalo $\mathrm{k}$ zaměstnancům $\mathrm{v}$ jeho působnosti způsobem tak degradujícím prestiž profese a požadované vzdělání pro její vykonávání. Aktuálně projednávanou novelou by se stát fakticky zřekl zodpovědnosti za kvalitu učitelů (přenesením této zodpovědnosti na ředitele škol), a tím i za kvalitu vzdělávání. I kdyby novela nakonec nebyla schválena, poselství ze strany vzdělávací politiky už poškodilo prestiž učitelské profese ve společnosti do dalších let zásadním způsobem.

Možná je tento př́stup ovlivněný faktem nedostatečných odborných kompetencí pracovníků MŠMT, ${ }^{29}$ který způsobuje problémy $\mathrm{v}$ tvorbě kvalitních legislativních návrhů včetně jejich věrohodného zdůvodnění. Závažné je zjištění, že novela prrinášející zásadní změny $\mathrm{v}$ př́stupu státu $\mathrm{k}$ učitelské profesi, která je od roku 2016 tzv. regulovanou profesí, není založena na expertních znalostech a relevantních výzkumných datech. $\mathrm{V}$ mnoha prípadech je doslova ignoruje nebo připravuje legislativní změny a intervence, které jsou s těmito daty $\mathrm{v}$ rozporu. To se týká např. výzkumně doloženého doporučení zdůrazňujícího vztah mezi kvalifikovaností a aprobovaností učitelů a vzdělávacími výsledky žáků. Kromě výzkumné sféry upozorňují na tuto vazbu např. i výroční zprávy České školní inspekce.

\footnotetext{
${ }^{29}$ Ministr ve svém dopise předsedům politických klubů ve Sněmovně explicitně uvádí, že návrh novely vychází $\mathrm{z}$ analytické práce MŠMT a reflexe současného systému ze strany ředitelů škol.
} 
Zcela markantní je opomíjení (nebo neznalost) klíčových trendů ve vyspělých zemích. Př́íkladem je zejména důraz na profesionalizaci učitelství a kvalitu př́ípravy na profesi, zvyšování požadavků na připravenost pro vstup do profese, ale i apel na podporu celoživotního profesního vzdělávání, které navazuje a dále rozvíjí přípravné vzdělávání učitelů. Zvyšování profesionality učitelů je všeobecně považováno za klíč ke zvyšování kvality školního vzdělávání. De-profesionalizační a de-kvalifikační novelou se česká vzdělávací politika vydává specifickou cestou, jde $\mathrm{v}$ protisměru $\mathrm{k}$ mezinárodním výzkumně doloženým trendům a doporučením.

Zkoumaný př́pad tvorby návrhu novely, jejího zdůvodňování a procesů politického rozhodování jasně ukazuje slabiny české vzdělávací politiky. Nelze ji $\mathrm{v}$ žádném př́ípadě považovat za výzkumně zdůvodněnou, opřenou o relevantní data, tedy za evidence-based či evidence-informed education policy (Veselý, Kohoutek \& Špačková, 2015) nebo knowledge-driven policy (Weiss, 1979; Štech, 2020).

Případ aktuálně projednávané novely je typickým př́kladem dlouhodobě nekoncepční, nekonzistentní vzdělávací politiky, chaotického rozhodování a nedostatečně zdůvodněných reálných intervencí, které jsou nezř́ídka v rozporu $s$ jinými strategickými záměry (např. se Strategií 2030 + představující zvýšené nároky na pedagogickou práci učitele, zejména na kvalitu jeho profesních kompetencí, tedy nejen oborových). V této souvislosti stojí za zmínku pozoruhodné přiznání několika politiků z řad poslanců i senátorů včetně samotného ministra, že v průběhu posledních 20 let neudělali pro podporu učitelské profese, zkvalitňování př́pravy na ni a celoživotní profesní rozvoj učitelů téměr nic.

Dodáváme, že ji až na pár výjimek svým nezájmem, podceňováním a spíše destruktivními zásahy postupně zbídačovali, až ji dovedli $\mathrm{k}$ současnému kritickému stavu, který neumějí řešit jinak než novelou vysílaným signálem, že učit může s nadsázkou „kdokoli“, míněno člověk bez profesního, učitelského vzdělání a bez praxe s výukou žáků. Je až absurdní, že nápad vpustit do profese pouze oborově vzdělané lidi přichází v době, kdy se české školství (uzavřené pro fyzickou docházku žáků a studentů extrémně dlouhou dobu) potýká s důsledky pandemické krize. Právě tato doba znovu potvrdila kruciální význam kvality pedagogicko-psychologických kompetencí učitelů v souvislosti se socializační funkcí školy a řešením psychických problémů generace „kovidiánü“, skupiny po seniorech považované za nejvíce ohroženou. Navíc toto poselství ze strany vzdělávací politiky poškozuje prestiž profese do dalších let devastujícím způsobem.

Z hlediska reflexe přístupů české vzdělávací politiky $\mathrm{k}$ učitelské profesi v delší časové perspektivě lze závěrem konstatovat, že namísto řešení př́čin problémů, návrhu opatření $\mathrm{k}$ jejich zmírnění, intervencí s perspektivou udržitelnosti budoucího vývoje se volí strategie "hašení požáru“ rychlým, nejjednodušším a krátkozrakým způsobem. Dlouhodobější perspektiva, založení vývoje nebo jeho přesměrování, 
jehož důsledky nejsou hned viditelné, není pro politiky dostatečně atraktivní. Přitom právě $\mathrm{v}$ případě novely by byl namístě pohled na problémy učitelské profese z hlediska perspektivy několika prríštích let. Zvyšování platů pedagogických pracovníků ve vazbě na hospodářský růst, na němž je široká politická shoda, ${ }^{30}$ může opět zvýšit atraktivitu učitelského povolání i zájem o studium pedagogických oborů či zvýšit šance na návrat pedagogických pracovníků, kteří z učitelské profese odešli z finančních důvodů a našli pracovní uplatnění jinde.

\section{Literatura}

Barber, M., \& Mourshed, M. (2007). How the world's best-performing schools come out on top. London: McKinsey.

Crone, L. J., \& Teddlie, C. (1995). Further examination of teacher behavior in differentially effective schools: Selection and socialization process. Journal of Classroom Interaction, 30(1), 1-12.

Darling-Hammond, L. (2000). Teacher quality and student achievement: A review of state policy evidence. Education Policy Analysis Archives, 8(1).

European Commission/EACEA/Eurydice (2018). Teaching careers in Europe: Access, progression and support. Eurydice report. Luxembourg: Publications Office of the European Union.

European Commission/EACEA/Eurydice (2021). Teachers in Europe: Careers, development and well-being. Eurydice report. Luxembourg: Publications Office of the European Union.

Hanusek, A. E., Kain, F .J., \& Rivkin, G. S. (2005). Teachers, schools, and academic achievement. Econometrica, 73(2), 417-458.

Hanušová, S. et al. (2017). Chtěji zůstat nebo odejit? Začinajicí učitelé v českých základních školách. Brno: Pedagogická fakulta MU.

Hattie,J. (2009) Teachersmakeadifference. What istheresearchevidence?Australian Council for Educational Research. Dostupné z www.det.nsw.edu.au/proflearn/docs/pdf/ qt_hattie.pdf

Kol. autorů (2021). Nedostatek kvalifikovaných učitelů nelze řešit rezignací na kvalifikaci. Pedagogika, 71(1), 120-125.

Kotásek, J. et al. (1991). Rozvaha o školstvi a vzdělanosti a jejich dalšim vývoji v českých zemích. Praha: Pedagogická fakulta UK.

Koucký, J. (2021). Učiteli̊ možná není vůbec málo. (Online). Dostupné z https://vzdelavani21.cz/ V21-21.html?news $=12163 \&$ locale $=\mathrm{cz}$

Koucký, J. (2020). Dưvody nedostatku učitelì. Úvodní studie z projektu. Dostupné z https:// pages.pedf.cuni.cz/nedostatekucitelu/author/24625498/

\footnotetext{
${ }^{30}$ https://pages.pedf.cuni.cz/nedostatekucitelu/platy-ucitelu-zdolavaji-rekordy/
} 
Maňák, J. (1995). Hlavní otázky profesionální př́pravy učitelů. In Teorie v pedagogické praxi, praxe v pedagogické teorii v učitelském studiu (s. 24-27). Brno: Paido.

Spilková, V. (2016). Př́stupy české vzdělávací politiky po roce 1989: Deprofesionalizace učitelství a učitelského vzdělávání? Pedagogika, 66(4), 368-385.

Spilková, V. et al. (2004). Současné promény vzděláváni učitelü. Brno: Paido.

Spilková, V., \& Wildová, R. (2014). Potřebujeme kvalitní, nebo kvalifikované učitele? Pedagogická orientace, 24(3), 423-432.

Štech, S. (2020). Trápení s užitečností pedagogického výzkumu: Jen ztraceni v překladu? Pedagogika, 70(1), 109-117.

Štech, S. (2021). Reakční novela zákona o pedagogických pracovnících. Deník Referendum. (Online). Dostupné z https://denikreferendum.cz/clanek/32201-reakcni-novela-zakona-o-pedagogickych-pracovnicich

Urbánek, P. (2005). Vybrané problémy učitelské profese. Aktuální analýza. Technická univerzita v Liberci.

Urbánek, P. (2013). Vzdělávání učitelů v České republice (po Česku): Riziko deprofesionalizace. In J. Ferencová \& I. Ištván (Eds.), Križovatky na cestách $k$ učitelstvu. Prešov: FHPV PU a Škola plus.

Veselý, A., Kohoutek, J., \& Špačková, Z. (2015). Vzdělávací politika. Brno: Ekonomicko-správní fakulta MU.

Vítečková, M. (2018). Začinajicí učitel: jeho potřeby a uvádèní do praxe. Brno: Paido.

Walterová, E. (1993). Výzkum v komparativní a mezinárodní pedagogice a jeho funkce v transformaci vzdělávání. Pedagogika, 43(4), 379-384.

Walterová, E. (2006). Srovnávaci pedagogika. Vývoj a promény v globálním kontextu. Praha: Pedagogická fakulta UK

Weiss, C. H. (1979). The many meanings of research utilization. Public Administration Review, 39(5), 426-431.

Zákon č. 197/2014 Sb., kterým se mění zákon č. 563/2004 Sb., o pedagogických pracovnících a o změně některých zákonů, ve znění pozdějších předpisů.

Závěrečná zpráva NERV (2011). Závèrečná zpráva podskupin Národni ekonomické rady vlády pro konkurenceschopnost a podporu podnikání. Kapitola III. Vzdělanost. (Online). Dostupné z www.vlada.cz/assets/media-centrum/aktualne/NERV_kap03.pdf

prof. PhDr. Vladimira Spilková, CSc.

Univerzita Pardubice, Fakulta filozofická, katedra anglistiky a amerikanistiky;

e-mail:vladimira.spilkova@email.cz

Mgr. Irena Reimannová, PhD.

Univerzita Pardubice, Fakulta filozofická, katedra anglistiky a amerikanistiky;

e-mail:irena.reimannova@upce.cz 


\section{SPILKOVÁ, V., REIMANNOVÁ, I. Interventions of Czech Educational Policy Compared to Research-Based Findings and Recommendations: The Case of Teaching Qualification Requirements}

The aim of the study is to analyse the approach of Czech educational policy to the qualification requirements for entry into the teaching profession, related to the currently discussed amendment to Act 563/2004 Coll., on educational staff and its controversial $\$ 9$ a. The investigation of the legislative definition of teaching qualification requirements in this amendment and the process of its debate aims at gaining comprehension and a deeper understanding of the relationship between political decision making and research-based findings and the way they are communicated to politicians.

The main research questions are: (1) What reasons for the reduction of qualification requirements in the de-professionalisation amendment were formulated by the submitter of the amendmentthe Ministry of Education, Youth and Sports and deputies and senators of the Parliament of the Czech Republic? (2) What arguments did politicians - both supporters and opponents of the amendment - present in their statements during the legislative process? (3) What opinions did other actors from the professional and general public express during the amendment debate?

The questions related to the case of the de-professionalisation and de-qualification amendment are followed by more general research questions: (1) How does Czech educational policy approach teaching as a regulated profession with certain occupational roles, the performance of which is regulated and limited? (2) How are research findings and research-based recommendations from the European and national levels used in Czech educational policy and in decision-making processes in the field of the teaching profession?

The study is based on the desk research methodology. Key data sources are: legislation (different versions of the amendment - deputies' and senator' copies of the amendment, amendatory proposals, stenographic records of meetings of both chambers of the Czech Parliament), professional and strategic documents (at the national and European levels), documents of the Ministry of Education, Youth and Sports, statements made by other important actors and press releases (professional associations, experts, non-profit organisations, posts on social networks - www.pedagogicka-komora.cz), and email communication between one of the authors of the article with parliamentary deputies and senators.

The discussion of the results reflects critically on the content and ways of justifying the devaluation of teaching qualification requirements expressed by politicians. The relevance and appropriateness

of the main reasons presented by the submitter of the amendment - the Ministry of Education, Youth and Sports - and other key legislative actors are evaluated. Furthermore, the extent of the relevant research data and recommendations used in the process of creating the amendment and political decision making in the legal requirements concerning teaching qualifications is assessed.

Keywords: educational policy, evidence-based approach, qualification requirements, research of the teaching profession, de-professionalisation of teaching, de-qualification amendment, de-professionalisation amendment 